\title{
DUBSLINGUISTIC Enhancing English Communication Skills among Malaysian Primary School Pupils
}

\author{
Nurain Adila Abdul Samat', Santhy Muthu², Melor Md. Yunus ${ }^{3}$ \\ ${ }^{1}$ SK Taman Sri Muda, Shah Alam, Malaysia \\ ${ }^{2}$ SK (LKTP) Jengka 10, Maran, Malaysia \\ ${ }^{3}$ Universiti Kebangsaan Malaysia, Bandar Baru Bangi, Malaysia \\ Email: ainadila93@gmail.com, santhymuthu31@gmail.com
}

How to cite this paper: Samat, N. A. A. Muthu, S., \& Yunus, M. Md. (2019). DUBSLINGUISTIC Enhancing English Communication Skills among Malaysian Primary School Pupils. Creative Education, 10, 48-58.

https://doi.org/10.4236/ce.2019.101004

Received: December 10, 2018

Accepted: January 11, 2019

Published: January 14, 2019

Copyright $\odot 2019$ by author(s) and Scientific Research Publishing Inc. This work is licensed under the Creative Commons Attribution International License (CC BY 4.0).

http://creativecommons.org/licenses/by/4.0/

\begin{abstract}
The exam oriented curriculum in Malaysia required pupils to be good in their writing skill while the latest Common European Framework of Reference (CEFR) wants pupils to communicate well in English Language. However, most Malaysian pupils are lacking in communication skill. As we know, communication involves verbal and non-verbal skills but more focus is given on verbal skill compared to non-verbal skills. Less focus is given on paralinguistic features which come under non-verbal aspect of communication. Therefore, "Dubslinguistic" was introduced to enhance pupils' communication skill in verbal as well as non-verbal. Few activities were conducted which catered to both verbal and non-verbal communication skills. A total of 40 pupils with the age range between $10-12$ years old from Shah Alam, Selangor and Maran, Pahang were chosen by using random sampling method. Data was collected using an action research approach. The checklist, survey questionnaire and semi-structured interview were conducted to measure the effectiveness of Dubslinguistic in enhancing pupils' verbal and non-verbal skills. The findings indicated that pupils were able to improve their verbal and non-verbal skills through activities implemented. Teachers and educators are encouraged to use Dubslinguistic to develop balanced pupils who are proficient in both verbal and non-verbal skills.
\end{abstract}

\section{Keywords}

Dubslinguistic, Verbal Skill, Non-Verbal Skill, Paralinguistic Features, Communication, Enhancing 


\section{Introduction}

Language is the most important medium of interaction and communication. It helps human to develop and ties the connection between one another. McLeod, Sumillera, Surman and Smirnova (2016) stated that language is a tool used to analyse the state of a human being and a tool to civilize people. Without language, people would be unable to understand one another as no one starts the conversation and no one can really speak their mind. In this globalization era, English has become one of the most important languages in the world. In Malaysia, Common European Framework of Reference (CEFR) was introduced with the aim to equip pupils with language that they will use to communicate in their daily life. This is aligned with Shift 2 in the Malaysia Education Blueprint (2013-2025) which intends to ensure that every child is proficient in Bahasa Malaysia and English language (MOE, 2011). However, most Malaysian primary school pupils face troubles in their speaking skills and are obsessed with examinations that the purpose of studying is not to gain knowledge anymore (Mihat, 2015). Zaki, Yunus, \& Hashim, (2017) agreed that Malaysian public standardized assessments only focus on reading and writing instead of the other two skills which are listening and speaking. This was proven by pupils from two different schools which are located in urban and sub-urban area in Malaysia. Those targeted Year 4 pupils were shy and timid in using their second language for various purposes. Most of them do not able to engage in simple conversation although the ability to carry out a conversation in the target language will determine the success in the classroom (Nunan, 1989). Therefore, the researchers have decided to integrate a lip-synch application named "Dubsmash" in enhancing communication. This study aims to use "Dubsmash" application in teaching and learning to enhance pupils' communication skill focusing on both verbal and non-verbal which leads into more interesting and successful learning sessions.

\section{Literature Review}

\subsection{Communication Skill}

Communication is outlined as a method of exchanging information. In this globalization era, oral communication skill in English language is highly needed for a competitive and expanding market economy (Khan, Khan, \& Ahmad, 2016). According to Lucanus (2017) process of socialization can be nurtured by good communication skill. It involves medium of speech to transmit thoughts and believes to other person. Pupils who are able to communicate effectively may build a good affiliation among each other. Besides, both pupils and teacher may gain benefit in the classroom. This is because language and communication skill conveys a significant role in developing pupils' social and personal development (Gillian, 2005). On the other hand, non-verbal communication is also known as important aspect of communication. According to Besson et al. (2005) non-verbal 
communication are messages convey through actions that such as body gestures, facial expressions and eye contact. Each element of non-verbal skill is interrelated to verbal skill in order to convey correct message. According to constructivist Jean Piaget's cognitive theory, the significance of non-verbal communication begins since we were new born who knows the world trough movements and sensations (Ojose, 2008). We started to learn the world by doing basic actions such as crying and grasping. Therefore, it is believed that humans begin to interact with non-verbal aspects. In terms of communication in the classroom, previous studies showed that non-verbal communication are majorly happened in the classroom compared to verbal. Bambaeeroo and Shokrpour (2017) mentioned that concepts explained trough spoken words are only 7\% in most teaching and learning process whereas more explanation were given using the movement of body, facial expression and other paralinguistic features. They also stated that pupils were being positive when non-verbal communication is used in learning the second language especially to learn vocabulary and comprehension. Likewise, Zeki (2009) also specified that eye contact is a time and energy saving non-verbal communication which can deliver message specifically compared to verbal communication. Hence, both verbal and non-verbal skills are very important for an individual to communicate effectively.

\subsection{Dubsmash Application}

Dubsmash is an electrical video communication created by Jonas Drüppel, Roland Grenke and Daniel Taschik. Users can download this application to record themselves dubbing to an audio recording or sound track (Figure 1).

This application permits the users to record their video with associate audio of their own voice recording or soundbite from movies, shows and music. Using Dubsmash application, researchers aim to implement teaching and learning activities by manipulating the app features to enhance pupils' verbal and non-verbal skill. A case study conducted by Abirami et al. (2018) indicated that pupils' communication skill in both verbal and non-verbal can be enhanced effectively by using Dubsmash application. In this research, pupils are encouraged to record their voice, facial expression, gestures as well as paralinguistic features like pronunciation, intonation, pitch and tone that they have learnt. On the other hand, pupils can also dub to the existing videos to portray their non-verbal skills such as facial expression, gestures and body language. Studies show that dubbing to the muted video clips is able to enhance pupils' linguistic skills (Akpan \& Beard, 2016). Therefore, this lip-synch application is chosen to be used in this study. Moreover, Dubsmash not solely enhances the ability of the learners but it entertains them too. As we know, kids nowadays are digital native (Loveland \& Love, 2017). By integrating Information, Communication and Technology (ICT) in learning, pupils engage in a fun learning environment and they will come back for more since it is so enjoyable (Yunus \& Suliman, 2014). Thus, using Dubsmash in the classroom is advisable to attract pupils' attention. 


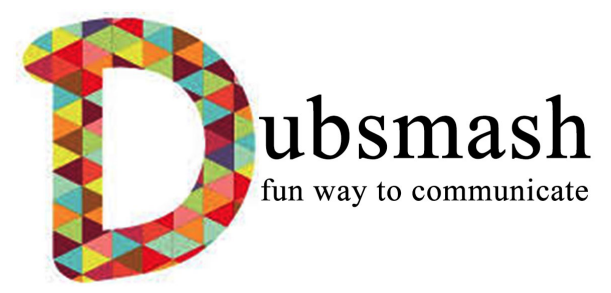

Figure 1. Dubsmash application.

\subsection{Communication Problems among Primary School Pupils}

Speaking skill is an issue among most primary school pupils in Malaysia. Even though pupils start to learn English at the age of 6, their English acquisition is not promising enough as evident in Malaysian scenario (Azman, 2016). It is believed that most Malaysian primary pupils are facing difficulties in learning the language due to some external factors. Similar problem also happened in Saudi Arabia and Thailand. Poonpon (2017) stated that Thai students are not really exposed to native English speakers and they do not have many chances to speak the language which makes them not to be able to speak well. It has also become a serious problem among students in Saudi Arabia as they also have poor English speaking ability (Khan, Khan, \& Ahmad, 2016). One of the reasons why pupils are not able to speak the language is the influence of the first language (Misbah, Mohamad, Yunus, \& Yaacob, 2017). Influence of the first language cause them to lose interest towards the learning of second language. Interest is an important aspect for learner to participate in the lesson. This is supported by Ur (2008) interesting topics with meaningful purpose motivate pupils to communicate with their friends and express themselves freely. Another reason is that pupils were nervous to speak out loud in the presence of a big crowd because they do not have any experience in using the language (Gillian, 2005; Scrivener, 2012). A study conducted by Yousef, Jamil and Razak (2013) indicated that most pupils in Malaysia are not confident to speak because of the anxiety they have within themselves. They also stated that pupils' willingness to speak in English is highly influenced with language learning communication strategies. Hence, something must be done in school in order to motivate pupils to practice the language in a non-threatening manner.

\section{Method}

\subsection{Research Design}

This study applies an action research design based on Kurt Lewin model to enhance teaching and learning practice of the researchers. Kurt Lewin's change management model is all about changes that can be made in order to see new challenge that can motivate and energize everyone. This model includes three essential stages which are unfreeze, change and freeze (Figure 2).

In order to improve pupils' communication skill, traditional way of teaching communication skill at unfreeze stage is changed by instilling "Dubslinguistic". 


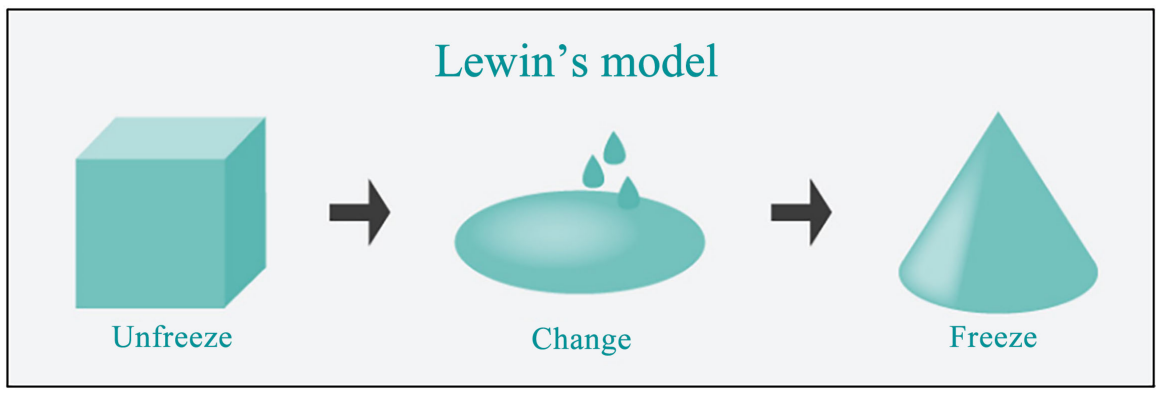

Figure 2. Kurt Lewin's change management model.

This technique is freeze to improve their verbal and non-verbal skills among pupils in this research. Action research is also conducted to collect data and evaluate the success of the intervention planned. Therefore, both qualitative and quantitative data gathered from observation checklist, survey questionnaires and semi-structured interview were analyzed and compared. Triangulation of data is also conducted to ensure the validity and reliability of the research findings.

\subsection{Respondents}

A total of 40 pupils were chosen to be the participants of this research. 20 pupils were from primary school located in Shah Alam, Selangor and another 20 pupils were from primary school located in Maran, Pahang. Their age range between 10 - 12 years old which were the upper primary level of pupils. They were from Year 4 to Year 6.27 (67.5\%) of them were girls and 13 (32.5\%) were boys. The pupils were chosen respectively based on the class that the researchers were assigned to teach at school. The participants were selected in this study based on random sampling method. This method was employed to ensure fairly equal representation of respondents.

\subsection{Procedure}

Pupils were assigned into groups. Each group consists of 4 members which forms a total of 10 groups. During the speaking lesson, 3 different activities which were charade, reader's theatre and role play were conducted in the classroom by incorporating Dubsmash application. Pupils were required to sit in groups only for reader's theatre and role play activity whereas individual learning happened during charade. The integration of the three activities with Dubsmash application is called Dubslinguistic. Dubslinguistic was conducted in teaching and learning for four weeks to ensure pupils were familiar with it. By the end of the Dubslinguistic activities, observation checklist and survey questionnaires were administered to all 40 pupils whereas 5 pupils from each school were chosen randomly to be interviewed. Below are the three Dubslinguistic activities:

Activity 1-Charade

Pupils required to record their gestures/facial expression/body language (non-verbal communication) in explaining words or phrases related to the topic 
in Year 4 textbook. 5 words were chosen to be shown to the whole class. For example, Unit 4 "Be Safe" and the 5 words or phrases are "burglar", "police", "neighborhood watch", "break into" and "lock the door". Using Dubsmash application, the recorded action is played in the classroom and pupils guess the answers and learn vocabularies at the same time.

Activity 2-Reader's Theatre

In groups, pupils were given with a short text related to the topic in Year 4 textbook. For example, a short text about house safety from Unit 4 "Be Safe". Pupils record their group members reading the text with correct pronunciation, intonation, pitch and tone of voice (paralinguistic features in verbal communication). The video from each group is played in the classroom. All groups were evaluated using the checklist given to see whether they expressed their verbal communication concentrating on paralinguistic features successfully.

Activity 3-Role play

In groups, pupils were given a situation to act out. The situation was given based on the topic in Year 4 textbook. For example, Unit 4 "Be Safe" and the situation given is "calling police to report burglary incident". Each group will get different situation. After creating their own script, pupils act the situation, say their lines with suitable pronunciation and intonation (verbal and non-verbal communication) and record the video using Dubsmash application. A checklist is given to all pupils to evaluate their friends' verbal and non-verbal communication.

\subsection{Data Analysis}

Based on the data collected, checklist with "Yes" or "No" indicators and survey questionnaires using Likert-scale were analyzed. Both quantitative and qualitative methods were implemented and the findings were reported using descriptive statistics and thematic coding respectively. The semi-structured interview responses were transcribed, coded and grouped into their respective themes. The private information of the interviewees was disclosed to ensure anonymity. Observation from the researchers on pupils' participation and behavior during the lesson was also considered in discussing the research findings.

\section{Findings and Discussion}

This section portrays the data collected from the Dubslinguistic activities in enhancing pupils' communication skill predominantly verbal and non-verbal aspect of communication. The three Dubslinguistic activities were assigned to evaluate pupils' non-verbal communication skill (charade), verbal communication skill (reader's theatre) and both verbal and non-verbal skill (role play). From the three Dubslinguistic activities, the findings of this research are aligned with the case study Abirami et al. (2018) conducted in India where the integration of Dubsmash application with teaching and learning is able to enhance pupils' communication skill. Not only that, the data also indicated that charade is the most favourite activity compared to reader's theatre and role play. However, 
role play is the most helpful activity in enhancing pupils' verbal and non-verbal skill based on the data gathered from the checklist. Below are the tabulated data from questionnaire and observation checklist (Table 1).

There were 7 items in the survey questionnaire. The items were simple and precise as Glanz (2014) and Mertler (2016) stated that a questionnaire should not be lengthy and has appropriate amount of items especially for young respondents. This is the reason why the smiley Likert scale was used which only contains Agree (smiley face), Neutral, and Disagree (sad face). As the respondents were primary school pupils, using the smiley Likert scale was more helpful to let them understood the choices they made. All the items given were also positive items so that it was direct and straightforward for the respondents. The first three items were related to the attractiveness and the beneficial aspects of the activities conducted while Item 4 and Item 5 were related to pupils' opinion regarding the use of Dubsmash application. Meanwhile, the last three items were related to pupils' communication skill. Thus, all the items in the questionnaire were helpful to the researcher to gain more understanding of this issue. Not only that, a semi-structured interview was also conducted so that a deeper and richer understanding of pupils' answers in the questionnaire could be obtained. The interview questions were intended to get pupils' explanation on how or why they like or dislike the Dubslinguistic activities. Pupils' opinion were transcribed and coded to see whether their responses matched with data gained from the questionnaire. On the other hand, the checklist was used during reader's theatre and role play activity. As verbal and non-verbal communication skills could not be measure on paper, checklist was the most suitable instrument to check whether pupils exhibit those skills during the lesson. All respondents were given the checklist so that they could evaluate their friends after the reader's theater activity or role play activity. The features or skills to be observed by the pupils were tabulated below in Table 2.

Table 1. Pupils' responses on "Dubslinguistic" activities.

\begin{tabular}{|c|c|c|c|c|}
\hline & Questions & $\begin{array}{l}\text { Disagree } \\
(\%)\end{array}$ & $\begin{array}{c}\text { Neutral } \\
(\%)\end{array}$ & $\begin{array}{c}\text { Agree } \\
(\%)\end{array}$ \\
\hline 1 & $\begin{array}{l}\text { Do you think charade activity is fun and helpful in English } \\
\text { communication? }\end{array}$ & 5 & 20.8 & 74.2 \\
\hline 2 & $\begin{array}{l}\text { Do you think reader's theatre activity is fun and helpful in } \\
\text { English communication? }\end{array}$ & 11.2 & 16.3 & 72.5 \\
\hline 3 & $\begin{array}{l}\text { Do you think role play activity is fun and helpful in English } \\
\text { communication? }\end{array}$ & 57.9 & 18.2 & 23.9 \\
\hline 4 & Do you think learning through Dubsmash is fun? & 3.5 & 6.2 & 90.3 \\
\hline 5 & Do you think it is easy to use Dubsmash in learning process? & 5.4 & 15.4 & 79.2 \\
\hline 5 & $\begin{array}{l}\text { Are the activities motivate you to give responses in the } \\
\text { classroom? }\end{array}$ & 3.4 & 13.2 & 83.4 \\
\hline 6 & Are the activities allow you to express yourselves? & 2.8 & 9.1 & 88.1 \\
\hline 7 & Are the activities enhance your confidence level to speak? & 2.6 & 11.7 & 85.7 \\
\hline
\end{tabular}


Table 2. Pupils' observation on their friends during reader's theater and role play activity.

\begin{tabular}{lrcr}
\hline & Items & Yes (\%) & No (\%) \\
\hline 1 & Does your friend pronounce the words appropriately? & 65 & 35 \\
2 & Is your friends tone of voice matches with the script/text? & 69.2 & 30.8 \\
3 & Is your friend's intonation suitable with the punctuation in the script/text? & 75.5 & 24.5 \\
4 & Is your friend's gestures well delivered with the situation? & 72.4 & 27.6 \\
5 & Does your friend communicate with confidence throughout the activity? & 76.9 & 23.1 \\
\hline
\end{tabular}

\subsection{Charade Activity}

This subsection presents pupils' responses regarding the use of Dubsmash application with charade activity in improving pupils' non-verbal communication skill. Data from the questionnaire indicated that $74.2 \%$ of the pupils agree that charade activity is helpful in improving their communication skill. Pupils believe that gestures, facial expression and body language help them to interpret the meaning of the words uttered by the speaker. Moreover, it attracts them to learn the English language better as they do not have to use only the spoken words while interacting with their friends and teacher in the classroom. Pupils found that spoken English is difficult and they were scared to use it. Pupil A said, " $I$ don't want to give responses to the teacher to avoid wrongness and embarrassment while learning". As the respondents come from intermediate proficiency level, they do not have good grasp in English communication. Charade activity requires them to act out the words only. This is the reason why charade is like the most compared to reader's theater and role play. Another $20.8 \%$ of the pupils were being neutral in giving their responses whereas $5 \%$ of the pupils disagree. Through the interview questions, Pupil $\mathrm{M}$ who disagreed stated that "Even without gesture or facial expression I can still understand what my friend said as I know the meaning of the words spoken" while pupil $\mathrm{H}$ responded "I am so lazy to guess the word because my friend's do not deliver the correct message". The data indicates that although charade helps improving pupils' non-verbal skill it will be not effective if the pupils do not understand the meaning of the words to be delivered.

\subsection{Reader's Theater}

The implementation of this activity with Dubsmash application is really helpful in improving pupils' verbal skill in communication. The features which were given focus throughout this activity were pronunciation, intonation and tone of voice. From the researcher observation, pupils were able to pronounce more words correctly compared to before engaging in this activity. Based on the checklist, $65 \%$ pupils agree that they learnt how to pronounce words correctly during the activity while $75.5 \%$ pupils also delivered appropriate intonation based on the punctuation used in the text. Pupil G commented " $I$ always increase my speech tone whenever I see exclamation mark in the sentence". Pupil 
$\mathrm{R}$ mentioned "I will correct my friend if they do not use correct tone for question mark". These responses are aligned with the data from the checklist. Pupils really learn the intonation because they want to ensure that they get high evaluation marks from their friend when the recorded video in Dubsmash is played to the whole class. Other than that, pupils also found that their friend's facial expression while reading the text is fun and interesting. $72.5 \%$ respondents agree that reader's theater is an engaging activity especially when it is implemented with Dubsmash application. This is compatible with the researcher's observation data where pupils gave more cooperation and attention when reader's theater activity was conducted compared with reading the textbook in an ordinary way. This data is also supported with pupils' responses in the interview. When Pupil S was asked "Why do you think reader's theater is fun?" the pupil said "It is fun because my friends laugh at me when I try to pronounce the word but at the same time I learn the correct pronunciation". Hence, the aspect of paralinguistic features in verbal communication is able to be practiced and achieved by the respondents through integration of reader's theater and Dubsmash application.

\subsection{Role Play}

The integration of Dubsmash application with role play activity intended to cater both verbal and non-verbal communication at the same time. Both aspects can be clearly seen when pupils deliver their lines and act out the scene. From the checklist and questionnaire data, $57.9 \%$ pupils responded that role play is the least favourite activity compared to charade and reader's theatre and only $23.9 \%$ pupils loved role play activity. Through the interview, data indicated that pupils were shy and intimidated to remember their lines in English language and act out the scene. Although the situation given is simple and related to their daily lives, pupils were scared to express themselves well. Pupil $\mathrm{N}$ said "I forget my lines and I don't know how to act well'. Apart from that, pupils responded in the questionnaire that role play is quite difficult as there are many things to do. For instance, pupils need to come out with script, remember the script, act out the scene and recorded the whole activity with Dubsmash application. Nevertheless, there were pupils who found that role play is beneficial for verbal and non-verbal skills. Pupil A mentioned "I acted like an actor when I do the role play. I use gestures, facial expression and suitable intonation like my favorite actor Zul Arifin". Pupil G also agreed saying that "I gave more focus to my facial expression and pronunciation when I am talking so that people understand what I am saying".

\section{Conclusion}

English teachers should think of innovative and engaging way for their language classroom. It can't be denied that corporation of technology in the classroom enables pupils to have more opportunities to explore learning. This increases motivation and pupils' engagement as well. Based on the findings it can be 
clearly said that "Dubslinguistic" enhances pupils' communication skill effectively. Educators need to be creative enough to develop interesting activities which incorporating technology to equip pupils with fun, meaningful and creative learning (Turner, 2013). A larger number of samples with much wider scope will be helpful in generalizing these research findings for future research. In a conclusion, the data collected shows that "Dubslinguistic" is able to enhance pupils' verbal and non-verbal communication skills. Hence, it is advocated for schools in Malaysia to implement Dubslinguistic in teaching and learning as it could help to shed new light in the learning of communication skill effectively.

\section{Conflicts of Interest}

The authors declare no conflicts of interest regarding the publication of this paper.

\section{References}

Abirami, K., Barathi, S., Koperundevi, E., Durgamani, M. K., \& Babu, M. I. (2018). Enhancing Paralinguistic Features through Dubsmash: A Case Study. International Journal of Pure and Applied Mathematics, 8, 1-6.

Akpan, J. P., \& Beard, L. A. (2016). Using Constructivist Teaching Strategies to Enhance Academic Outcomes of Students with Special Needs. Universal Journal of Educational Research, 4, 392-398.

Azman, H. (2016). Implementation and Challenges of English Language Education Reform in Malaysian Primary Schools. 3L: Language, Linguistics and Literature. The Southeast Asian Journal of English Language Studies, 22, 65-78. https://doi.org/10.17576/3L-2016-2203-05

Bambaeeroo, F., \& Shokrpour, N. (2017). The Impact of the Teachers' Non-Verbal Communication on Success in Teaching. Journal of Advances in Medical Education \& Professionalism, 5, 51-59.

Besson, C., Graf, D., Hartung, I., Kropfhausser, B., \& Voisard, S. (2005). The Importance of Nonverbal Communication in Professional Interpretation. http://aiic.net/p/1662

Gillian, B. (2005). The Importance of Oral Language in the School Curriculum. Unpublished M.A. Dissertation, New York: New York University.

Glanz, J. (2014). Action Research: An Educational Leader's Guide to School Improvement. United Kingdom: Rowman and Littlefield.

Khan, M. R., Khan, S. R., \& Ahmad, S. (2016). Student's Perceptions about the Importance of Communication Skills: A Case Study of EFL Learners at Jazan University, Saudi Arabia. International Journal of English Language Education, 4, 63-78. https://doi.org/10.5296/ijele.v4i1.8782

Loveland, T., \& Love, T. S. (2017). Technological Literacy: The Proper Focus to Educate All Students. The Technology and Engineering Teacher, 76, 13-17.

Lucanus, A. (2017). Oral Communication Skills Are Important for Students. https://collegepuzzle.stanford.edu/oral-communication-skills-are-important-for-stude nts/

McLeod, M., Sumillera, R. G., Surman, J., \& Smirnova, E. (2016). Language as a Scientific Tool: Shaping Scientific Language across Time and National Tradition. New York: Routledge. https://doi.org/10.4324/9781315657257 
Mertler, C. A. (2016). Action Research: Improving Schools and Empowering Educators. United States of America: SAGE Publications, Inc.

Mihat, W. (2015). The English Language Curriculum in Malaysian Indigenous Primary Classrooms: The Reality and the Ideal. 3L: Language, Linguistics and Literature. The Southeast Asian Journal of English Language Studies, 21, 1-12.

Ministry of Education MOE (2011). Malaysia Education Blueprint 2013-2025. Kuala Lumpur: Kementerian Pendidikan Malaysia.

Misbah, N. H., Mohamad, M., Yunus, M. M., \& Yaacob, A. (2017). Identifying the Factors Contributing to Students' Difficulties in the English Language Learning. Creative Education, 8, 1999-2008. https://doi.org/10.4236/ce.2017.813136

Nunan, D. (1989). Designing Tasks for the Communication Classroom. New York: Cambridge University Press.

Ojose, B. (2008). Applying Piaget's Theory of Cognitive Development to Mathematics Instruction. The Mathematics Educator, 1, 26-30.

Poonpon, K. (2017). Enhancing English Skills through Project-Based Learning. The English Teacher, 2, 1-10.

Scrivener, J. (2012). Learning Teaching: MacMillan Books for Teachers: Speaking Your Mind, Oral Presentation and Seminar Skills. London: Pearson Education Ltd.

Turner, S. (2013). Teachers' and Pupils' Perceptions of Creativity across Different Key Stages. Research in Education, 89, 23-40. https://doi.org/10.7227/RIE.89.1.3

Ur, P. (2008). A Course in Language Teaching: Practice and Theory: Trainer's Handbook. Cambridge: Cambridge Teacher Training and Development.

Yousef, R., Jamil, H., \& Razak, N. (2013). Willingness to Communicate in English: A Study of Malaysian Pre-Service English Teachers. English Language Teaching, 6, 205-216. https://doi.org/10.5539/elt.v6n9p205

Yunus, M. M., \& Suliman, A. (2014). Information and Communication Technology (ICT) Tools in Teaching and Learning Literature Component in Malaysian Secondary Schools. Asian Social Science Journal, 7, 136-152.

https://doi.org/10.5539/ass.v10n7p136

Zaki, M. H. S., Yunus, M. M., \& Hashim, H. (2017). The Use of Audio Visual Aids in Developing Pupils' Speaking Skills: Malaysian Context. Asian Social Science Journal, 4, 165-172.

Zeki, C. P. (2009). The Importance of Non-Verbal Communication in Classroom Management. Procedia Social and Behavioral Sciences, 1, 1443.

https://doi.org/10.1016/j.sbspro.2009.01.254 